\title{
Dampak Kanker Payudara dan Pengobatannya Terhadap Aspek Bio-psiko-spiritual Klien yang Berpartisipasi Dalam Kelompok Pendukung
}

\section{Elly Nurachmah}

Dosen KMB FIK-UI, Ketua PS Magister Kepemimpinan dan Manajemen Keperawatan, FIK-UI

Penelitian fenomenologis ini telah mengkaji aspek bio-psiko-sosio-spiritual klien pengidap kanker payudara yang tengah mendapatkan pengobatan. Data kualitatif dalam bentuk catatan lapangan telah dikumpulkan selama pelaksanaan program kelompok pendukung. Maksud penelitian ini adalah untuk mendapatkan pemahaman yang mendalam tentang bagaimana wanita Indonesia yang mengidap kanker payudara merasakan pengalaman yang kompleks, sangat interpersonal, dan dinamis. Latar belakang pemikiran dari penelitian ini didasari oleh pengertian bahwa untuk mendapatkan pengetahuan tentang sesuatu akan menjadi sia-sia dan hamper tidak mungkin tanpa menerangkan pengalaman individu sebagaimana adanya ketika dialami dan sebagaimana diterangkan oleh individu itu secara langsung (Polit, 1996). Tujuan penelitian ini adalah untuk mengkaji dampak kanker payudara dan pengobatannya terhadap aspek (a) fisiologis, (b) keseimbangan psikologis, (c) hubungan klien dengan orang lain, (d) nilai-nilai spiritual, dan (e) kualitas kehidupan keseharian klien. Subyek penelitian terdiri dari 87 wanita dengan diagnosa kanker payudara yang menghadiri kelompok pendukung. Hasil analisa kualitatif berasal dari analisis isi komentar dan pernyataan subyek selama mengikuti kegiatan kelompok pendukung telah mendapatkan lima kategori thema yaitu: ketidak-mampuan fisiologis (physiological incapability), ketidak-seimbangan psikologis (psychological disequilibrium), perilaku negatif dalam hubungan social (social relationship misbehavior), disparitas nilai-nilai spiritual )spiritual values disparity), dan kehidupan bersemangat (life of courage). Setiap penyataan dinilai dan diinterpretasikan menjadi thema, kelompok thema, kategori thema. Kesimpulan hasil riset telah menunjukkan bahwa partisipasi kelompok dalam kelompok pendukung telah menolong mereka untuk membentuk perasaan positif tentang diri mereka sendiri dan meningkatkan kemampuan mereka dalam berkomunikasi dengan pasangan hidup dan anggota keluarga lainnya.

Kata kunci: kanker payudara, kelompok pendukung, kategori thema.

This phenemonological study explored bio psycho social spiritual aspects of Indonesian women with breast cancer who were having therapy. A qualitative data in a form of field notes was obtained during the course of the support group program. The main objective was to have a deeper and richer understanding on how Indonesian women with breast cancer made sense of an experience that was complex, interpersonal, and dynamic. The premise was that gaining knowledge would be impossible without describing human experience as it was defined by the persons themselves (Polit, 1996). The purpose of the study was to explore the impact of breast cancer and its treatment on their (a) physiological aspects, (b) physiological equilibrium, (c) relationship with others, (d) spiritual values, and quality of daily living. Eighty seven subject who joined the support group for women with breast cancer participated in the study. The result of qualitative analysis which were extracted from the significant 
statements and comments made by the subject during the course of the breast cancer support group for women with breast cancer participated in the study. The result of qualitative analysis which were extracted from the significant statements and comments made by the subject during the course of the breast cancer support group program identified five theme categories : physiological incapability, physiological disequilibrium, social relationship misbehavior, spiritual values disparity, and life of courage. Each statement was examined and interpreted in relation to themes, theme group, and theme categories. The result of the study concluded that group participation had helped them to have positive feelings about themselves and improved their communication skills with their spouses and other family members.

Key words: breast cancer, support group, theme categories. 